\title{
STUDI RESPON HARMONIS PONDASI MESIN TIPE PORTAL DENGAN SISTEM JEPIT DAN SSI
}

\author{
Muhammad Imaduddin ${ }^{(1)}$ dan Ananta Sigit Sidharta ${ }^{(2)}$ \\ (1) Fakultas Teknik, Universitas Negeri Surabaya \\ (2) Fakultas Teknik dan Perencanaan, Institut Teknologi Sepuluh Nopember Surabaya \\ email: muhammadimaduddin@unesa.ac.id
}

\begin{abstract}
Abstrak
Bidang struktur dan Geoteknik mempunyai hubungan yang erat dalam analisis struktur teknik sipil. Beberapa analisis yang dilakukan secara mandiri pada bidang-bidang tersebut sering kali hasilnya kurang akurat. Untuk mendapatkan perilaku yang realistis dari struktur atas, tanah dasar harus dimodelkan dengan baik. Di sisi lain, dibutuhkan pemodelan struktur yang lebih baik untuk mendapatkan respon tanah yang tepat. Untuk mendapatkan perilaku yang tepat dari struktur dan tanah dalam satu model, model yang di analisis harus menyertakan interaksi tanah-struktur yang baik. Struktur yang ditinjau adalah pondasi mesin tipe portal yang terletak di atas lempung lunak. Respon yang terjadi dibandingkan dengan respon struktur yang perletakannya jepit untuk mendapatkan suatu kondisi di mana pondasi bisa dianggap sebagai struktur dengan perletakan jepit dengan tetap memperhitungkan terjadinya efek SSI. Kondisi ini tercapai pada model dengan perbandingan lebar-tinggi portal yang berbanding lurus terhadap perbandingan kekakuan balok-kolom pada skala logaritmis dengan kemiringan garis $-1,13$.
\end{abstract}

Kata kunci: pondasi mesin tipe portal; interaksi tanah-struktur; kekakuan

\begin{abstract}
Structural engineering and geotechnics are closely connected subjects in analysis of civil engineering structures, often analysis in neither of the two subjects can be performed independently with accurate results. To get the superstructure's real behavior, the subgrade must be modeled sufficiently well. On the other hand, an advanced model of superstructure needed to get the correct response in the subgrade. To capture the right behaviors of both superstructure and subgrade in one model, it must include a good soil-structure interaction (SSI). Framed type machinery foundation structure built on soft clay is used as a model. it's response compared to fixed-base model to find-out fixed-base condition of model, where structure's responses that considering soil-structure interaction effect could be analyzed using fixed-base model. The condition was reached on model with length-height ratio of frame has linear relation to beam-column stiffness ratio in logarithmic scale with gradient -1.13.
\end{abstract}

Keywords: framed type machine foundation; soil-structure interaction; stiffness

\section{PENDAHULUAN}

Bidang struktur dan Geoteknik mempunyai hubungan yang erat dalam analisis struktur teknik sipil. Beberapa analisis yang dilakukan secara mandiri pada bidang-bidang tersebut sering kali hasilnya kurang akurat. Untuk mendapatkan perilaku yang realistis dari struktur atas, tanah dasar harus dimodelkan dengan baik. Di sisi lain, dibutuhkan pemodelan struktur yang lebih baik untuk mendapatkan respon tanah yang tepat. Untuk mendapatkan perilaku yang tepat dari struktur dan tanah dalam satu model, model yang di analisis harus menyertakan interaksi tanah-struktur yang baik (Aron, C and Jonas, E, 2012). Perletakan yang dimodelkan dengan menyertakan tanah sebagai sistem struktur adalah mengingat bahwa respon struktur sangat tergantung pada penurunan yang terjadi pada tanah. Sehingga bisa dikatakan bahwa struktur pondasi pada kenyataannya tidak pernah benar-benar terjepit sebagaimana anggapan yang umum digunakan pada saat perencanaan. Sebagaimana ditegaskan oleh Mylonakis, 
G. and Gazetas (2000) bahwa anggapan struktur atas yang relatif ringan berdiri di atas tanah yang relative kaku tidak selalu tepat. Kolekova, Petronijevic, Schmid (2010) menyatakan bahwa banyak masalah teknik gempa membutuhkan pemodelan struktur sebagai sistem yang dinamis yang memasukkan tanah dasar dalam perhitungannya. Seorang ahli struktur sudah terbiasa dengan metode elemen hingga namun memiliki masalah pemodelan dengan tanah dasar ketika ekstensi yang tak terbatas dan propagasi gelombang menjadi fitur penting. Ketika ada gaya luar yang bekerja pada system, displacemen antara styruktur dan tanah tidak ada yang berdiri sendiri. Keduanya salaing mempengaruhi satu sama lain (Tuladhar, Maki, Mutsuyoshi, 2008). Dalam kasus beban dinamik gempa, kerusakan yang berkelanjutan pada gempa Kobe 1995 menegaskan bahwa perilaku seismic struktur sangat dipengaruhi oleh struktur atas dan bawah secara secara bersamaan (Mylonakis, Gazetas, Nikolaou, Michaelides, 2000). Oleh karena itu, standar disain modern menetapkan bahwa analisis respon harus mempertimbangkan system struktur secara keseluruhan termasuk struktur atas, pondasi, dan tanah, JSCE (2005).

Untuk struktur yang terletak di atas tanah yang bisa berdeformasi, pergerakan pondasi biasanya tidak sama dengan pergerakan tanah dan suatu komponen getaran yang memutar sumbu memanjang struktur kemungkinan bisa terjadi sebagai akibat dari suatu komponen lateral atau komponen translasi. Komponen getaran tersebut tersebut bersama-sama dengan efek interaksi tanah-struktur berakibat sangat besar pada struktur yang mempunyai kekakuan lateral besar, terutama yang terletak di atas tanah lunak. Pengaruh SSI sangat kecil pada struktur fleksible di atas tanah tanah keras, sementara pada struktur kaku di atas tanah lunak pengaruh SSI cukup besar, . Respon struktur yang terletak di atas sistem pondasi pada tanah yang bisa berdeformasi ini disebut respon perletakan fleksibel.

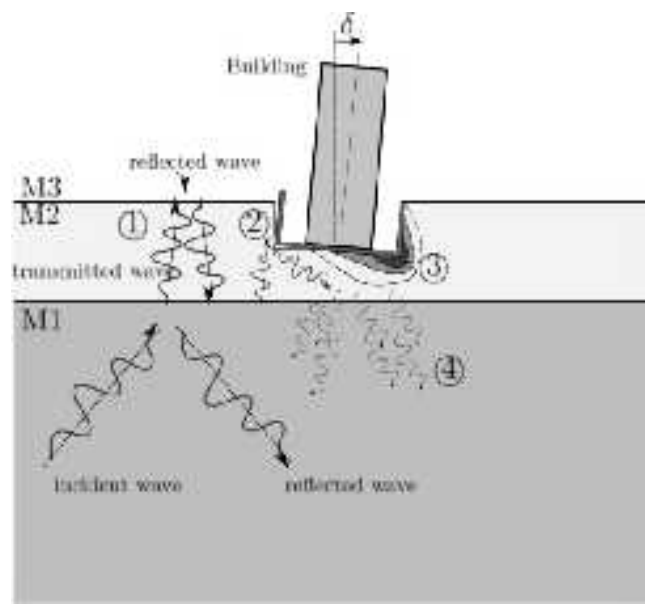

Gambar 1. Sistem Struktur dengan SSI (Sumber: Grange, 2013)

Dalam hal energi getaran, struktur dengan perletakan fleksibel berbeda dengan struktur yang perletakannya jepit. Energi getaran struktur akan disebarkan ke dalam medium pendukungnya melalui radiasi gelombang-gelombang dan perilaku histerisis dalam tanah. Efek balik dari penyebaran energi ini tidak diperthitungkan dalam struktur dengan sistem perletakan jepit. Perbedaan efek yang terjadi pada perletakan fleksibel dan jepit sangat tergantung dari karakteristik struktur dan medium tanah yang mendukungnya. Oleh karena itu, pemasukan efek interaksi tanahstruktur (SSI) menjadi penting sekali dalam analisis struktur terutama untuk struktur yang menerima beban dinamis.

Stewart, Cormatin, Muehle (2004) menyatakan ada tiga kategori utama dalam efek SSI: pengenalan fleksibilitas untuk sistem tanah-pondasi yang menghasilkan perpanjangan periode respon dasar dari sistem (efek pondasi fleksibel), penyaringan karakter getaran tanah yang disalurkan ke 
struktur (efek kinematik), dan disipasi energi dari sistem tanah-struktur melalui radiasi dan histerisis redaman tanah (efek peredaman pondasi). Sementara aspekaspek dalam SSI menurut Grange (2013), yaitu: pembesaran gelombang akibat perbedaan property tanah pada lapisan yang berbeda, efek inersia dan kinematis yang berdampak pada strutur, efek non linier pada bidang pertemuan struktur dan tanah, dan pemancaran redaman. Pada umumnya, studi mengenai efek SSI pada respon struktur meliputi dua kondisi: yang pertama berkaitan dengan evaluasi efek SSI pada respon struktur yang direncanakan dengan analisis konvensional tanpa memasukkan efek interaksi; kondisi kedua mempertimbangkan kerja sama efek SSI ke dalam perencanaan dan algoritma. Dalam penelitian ini, akan dilakukan pendekatan dengan kedua cara tersebut di atas dan hasilnya akan dibandingkan.

Satu kecenderungan untuk menganggap bahwa memodelkan tanah adalah lebih sulit dari pada struktur. Bagaimanapun juga, dalam kondisi penurunan, membuat model nonlinier timedependent adalah tidak menguntungkan kecuali jika struktur juga dimodelkan dengan cara yang sama. Perbedaan penurunan sudah dapat diprediksi dengan akurat tetapi beberapa di antaranya diperoleh dengan melakukan ekstrapolasi dari observasi dibandingkan dengan memprediksi dengan model. Dengan analisis secara numerik dan didukung oleh perangkat keras dan perangkat lunak yang memadai, kita bisa melakukan simulasi suatu model struktur secara virtual.

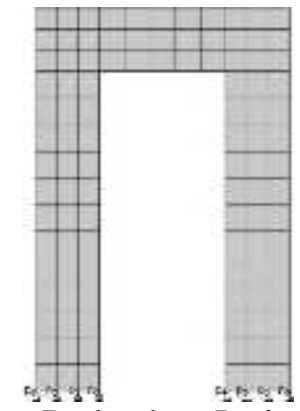

a. Perletakan Jepit

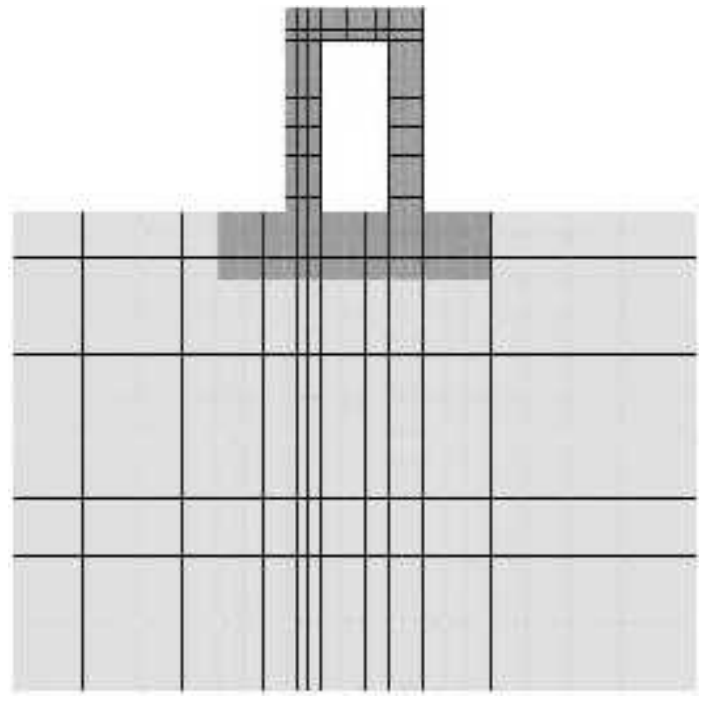

b. Interaksi Struktur - Tanah

Gambar 2. Pemodelan Pondasi Mesin Tipe Portal dengan Perletakan Jepit dan SSI

Dalam Gambar 2 nampak model pondasi mesin tipe portal yang terletak di atas tanah untuk sistem perletakan jepit penuh dan SSI. Dalam kondisi perletakan yang terjepit, struktur bagian bawah dan tanah tidak diikutsertakan dan bagian dasar kolom dianggap terjepit penuh di atas tanah. Untuk menunjukkan model yang lebih teliti dari struktur pondasi mesin tersebut, pemodelan dilakukan dengan memasukkan efek SSI dalam sistem struktur, di mana sistem ditampilkan secara menyeluruh meliputi struktur, pondasi dan tanah. Model tersebut menggunakan elemen solid45 yang merupakan salah satu elemen solid yang digunakan dalam pemodelan 3D, ANSYS (2005). Hubungan antara pondasi dengan tanah dianggap terikat sepenuhnya, sehingga dasar pondasi dan permukaan tanah yang menempel pada pondasi akan bergerak secara bersamaan, Suleyman, Yalcin (2000).

Respon struktur dengan kedua pemodelan tersebut akan dievaluasi terhadap beban dinamis mesin yang dipikulnya. Amplitudo yang terjadi pada frekuensi kerja mesin, baik arah sumbu $\mathrm{X}$ (horizontal) maupun arah sumbu $\mathrm{Y}$ 
(vertikal), pada pembebanan dinamis vertikal dan horizantal, pada masingmasing kondisi akan dibandingkan dan diberikan hubungannya dalam bentuk grafik. Hasil yang diperoleh bisa digunakan sebagai alternatif pertimbangan pada saat melakukan perencanaan pondasi mesin tipe portal.

Beberapa faktor yang perlu diperhatikan dalam suatu model yang mengombinasikan struktur dan tanah adalah:

1. Secara normal, penurunan terjadi dalam jangka panjang dan karenanya perlu dimodelkan perilaku tanah nonlinier yang tergantung waktu. Perangkat lunak dengan kemampuan seperti ini sangat mahal dalam penggunaannya dan cenderung memberikan prediksi dengan keandalan yang rendah.

2. Model-model untuk kekakuan struktur juga membutuhkan perhitungan perilaku jangka panjang. Pada struktur baja, pengaruh jangka panjang tidak terlalu penting. Tetapi pada beton, efek dari susut, retak dan rangkak bisa menjadi sangat berarti dibandingkan deformasi elastisnya. Untuk pasangan batu, efek faktor waktu sangatlah kecil tetapi untuk performance jangka panjang tidak bisa diabaikan.

3. Pengaruh elemen-elemen nonstruktural pada gedung seperti: partisi dan cladding, memberikan efek yang penting pada kekakuan aktualnya.

4. Kerusakan akibat penurunan biasanya disebabkan oleh penurunan yang tidak seragam. Faktor utama penyebab perbedaan penurunan adalah variasi kekakuan tanah di bawah struktur. Jika demikian, maka variasi ini hendaknya menjadi parameter utama dari model tanah. Biasanya hal ini tidak umum untuk dimasukkan dalam model interaksi struktur - tanah (SSI).

Wahyudi (2006), membahas masalah pondasi mesin tipe portal ini untuk sistem SSI dengan memodelkan tanah sebagai pegas-pegas dan memberikan taper pada kolom $(\alpha=0,1-1,3)$. Hasil yang didapatkan adalah perubahan respon horisontal frekuensi struktur sebesar 5\% $77 \%$ untuk perletakan jepit. Sedangkan untuk model SSI didapatkan: 2,97\% $22,24 \%$ (lempung), 2,67\% - 50\% (lempung keras) dan 3,07\% - 45,32\% (tanah pasir). Penelitian tersebut membahas tentang perubahan respon horisontal dengan penambahan taper pada kolom-kolom pondasi mesin dan efek SSI dilakukan dengan memodelkan tanah sebagai pegaspegas sesuai dengan properti tanah yang ditinjau. Penelitian yang lain berkenaan dengan SSI, Tsogka and Wirgin (2003), mempelajari tentang respon group dari bangunan yang berdiri diatas lapisan tanah lunak. Selain itu juga, Padron et al. (2009) mempelajari SSI secara dinamis di dekat tiang pancang bangunan dengan beban gempa dengan menggunakan model elemen hingga.

Tinjauan utama dalam tulisan ini adalah mengetahui respon struktur pada frekuensi kerja yang terjadi berdasarkan analisis dinamis yang dilakukan secara numerik pada struktur pondasi mesin tipe portal sehubungan dengan variasi kekakuan pada elemen balok dan kolom dengan mempertimbangkan interaksi yang terjadi antara struktur pondasi mesin tipe portal, beban dinamis mesin dan tanah di sekitar pondasi. Pemodelan numerik untuk pondasi, beban dinamis, dan tanah didiskripsikan dengan menggabungkan ketiga unsur tersebut sebagai satu sistem struktur. Dalam hal ini tanah dimasukkan sebagai bagian dari model struktur di mana besarnya volume tanah yang diikutkan dalam model ditentukan dengan melakukan analisis awal sampai didapatkan besarnya tegangan yang relatif sangat kecil. Tegangan yang relatif kecil ini menggambarkan bahwa sudah tidak ada pengaruh yang berarti pada area tanah tersebut dan area tanah yang lebih jauh lagi.

\section{METODE}

Metode yang digunakan dalam mencari respon struktur adalah dengan melakukan simulasi terhadap model struktur dengan bantuan perangkat lunak analisis struktur yang sesuai. Model 3D struktur merupakan representasi matematis dari bangun struktur yang sesungguhnya. Dengan demikian model yang dibuat harus mampu mewakili kondisi yang sebenarnya sejauh hal tersebut dimungkinkan. Hal ini tergantung dari kelengkapan fasilitas dan kemampuan yang dimiliki oleh program bantu tersebut. 
Dimensi fisik, sifat-sifat bahan, kondisi perletakan dan variasi nilai dan distribusi beban yang bekerja merupakan data masukan bagi program dalam melakukan simulasi terhadap model. Simulasi ini akan dilakukan pada dua kondisi perletakan yang berbeda, yaitu: perletakan yang terjepit penuh dan perletakan yang menyertakan tanah dan struktur bawah dalam proses analisis.

\section{Penyusunan Model}

Pondasi mesin yang ditinjau adalah tipe portal yang memikul generator gas turbin seperti yang terpasang di pabrik PT. Ajinomoto - Mojokerto. Mesin ini bekerja pada putaran $1500 \mathrm{rpm}$ atau $25 \mathrm{~Hz}$, sehingga sesuai dengan kategori secara umum berdasarkan frekuensi operasi mesin, maka generator tersebut masuk dalam kriteria frekuensi sangat tinggi. Berdasarkan hal ini, pondasi yang dipilih adalah tipe portal. Beberapa keunggulan dari tipe portal meliputi: kebutuhan ruang yang lebih ringkas, penghematan material, akses yang mudah pada semua bagian mesin untuk keperluan inspeksi dan pengaruh yang kecil terhadap retak akibat penurunan tanah dan perubahan suhu.

Pondasi portal ini tersusun dari pelat pondasi (sole plate) di bagian bawah yang langsung didukung oleh tanah. Pelat ini mendukung kolom-kolom yang di ujung atasnya dihubungkan dengan balok-balok memanjang dan melintang membentuk suatu bagian atas yang kaku (table-plate). Di bagian table plate inilah tempat perletakan gas turbin generator.

Mesin yang dipikul secara keseluruhan adalah berupa paket yang kompak, sehingga pembenan dianggap terdistribusi secara merata

proporsional pada masing-masing perletakan yang terdiri atas enam titik perletakan yang terletak pada pertemuan balok dan kolom. Berat total paket mesin gas turbin generator ini adalah 50 ton.

\section{Geometri Model}

Struktur yang ditinjau adalah sebuah pondasi mesin tipe portal dari beton bertulang. Gambar 3 menunjukkan potongan melintang dan memanjang dari pondasi tersebut. Dengan kaki-kaki mesin (perletakan mesin) yang berjarak $4 \mathrm{~m}$ ke arah memanjang dan $1,65 \mathrm{~m}$ ke arah melebar maka dimensi pondasi mesin tipe portal dapat ditentukan dengan lebar 1,75 m dan tinggi $3 \mathrm{~m}$. Digunakan tiga buah portal dengan jarak antar portal sebesar $4 \mathrm{~m}$ (dari as-as). Sole-plate berukuran $4 \mathrm{~m} \mathrm{x} \mathrm{10,5} \mathrm{m}$ dengan ketebalam 1,0 m. Seluruh kolom dan balok berukuran $50 \mathrm{~cm}$ x $50 \mathrm{~cm}$.
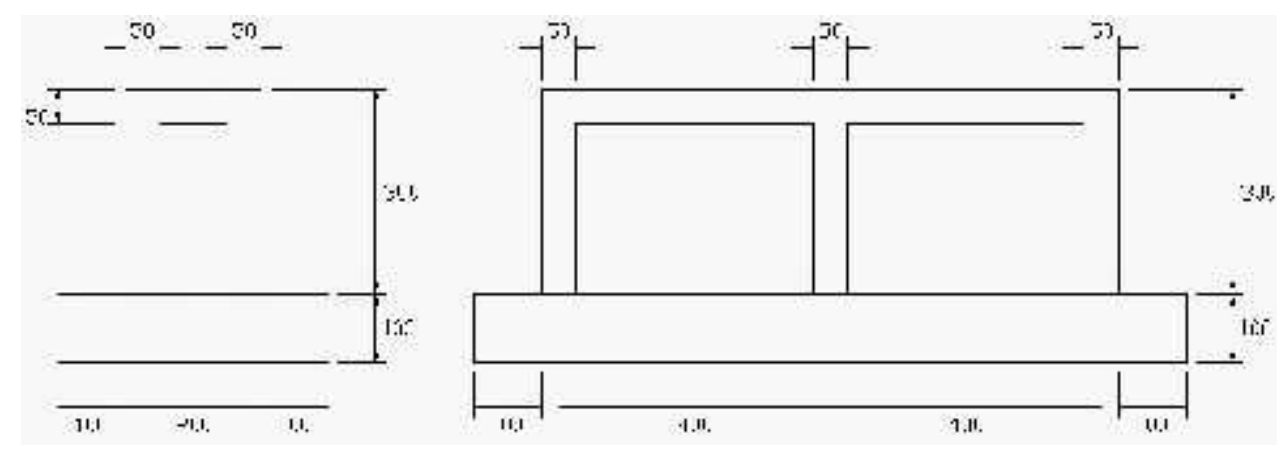

Gambar 3. Dimensi Pondasi Mesin

Untuk model SSI, seperti pada Gambar 4, volume tanah yang dimodelkan meliputi: lebar $b=10 \mathrm{~m}$, panjang $l=16,5 \mathrm{~m}$ dan kedalaman $\mathrm{h}=7 \mathrm{~m}$. Luasan ini ditentukan dari distribusi tegangan yang terjadi pada tanah pada saat pembebanan oleh pondasi dan mesin. Batas tanah diambil pada daerah di mana tegangan yang terjadi pada tanah relatif kecil atau sama. Selanjutnya tampak perspektif dari model SSI ini adalah seperti pada Gambar 5. 


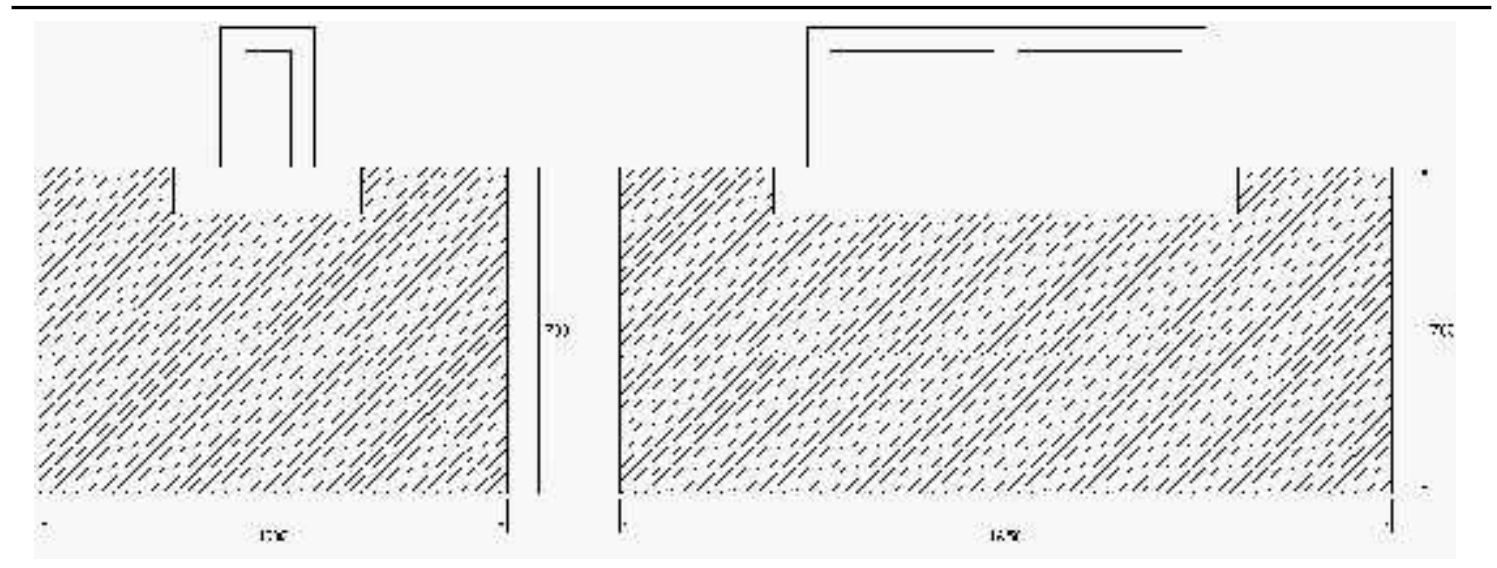

Gambar 4. Volume Tanah Pada Model SSI

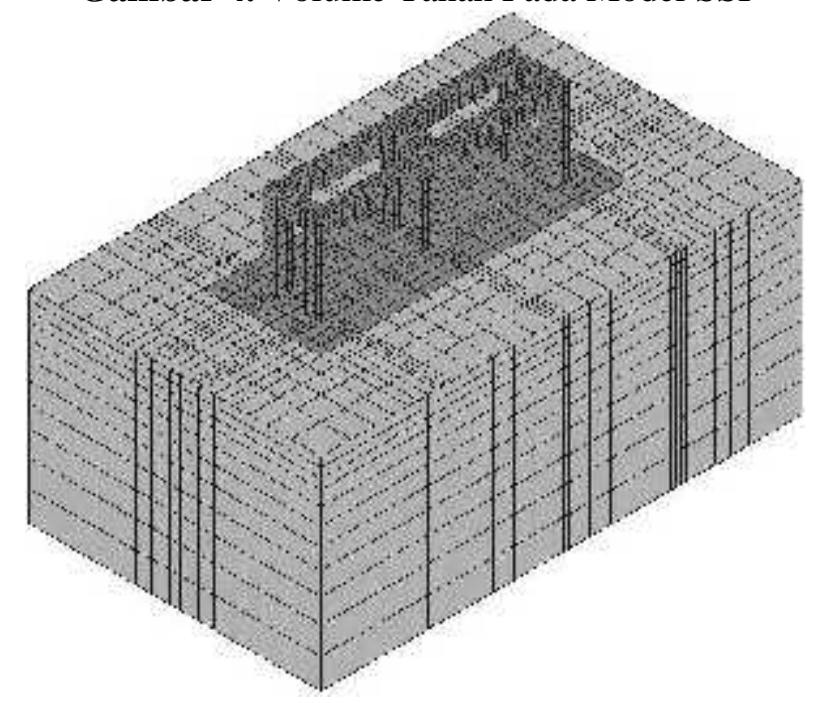

Gambar 5. Pemodelan Pondasi dengan Sistem SSI

Dalam Gambar 6 menunjukkan distribusi tegangan yang terjadi dalam tanah akibat pembebanan pondasi mesin. Angkaangka yang tertulis menggunakan satuan SI, di mana untuk tegangan menggunakan satuan $\mathrm{kg} / \mathrm{m}^{2}$. Sesuai dengan warna kontur tegangan, terlihat bahwa tegangan yang terjadi pada tanah di daerah tepi luar menunjukkan gradasi yang sama yang mewakili besar tegangan $0,14 \mathrm{~kg} / \mathrm{m}^{2}$ atau sama dengan $0,000014 \mathrm{~kg} / \mathrm{cm}^{2}$. Ini adalah tegangan tanah dengan nilai yang relatif sangat kecil.

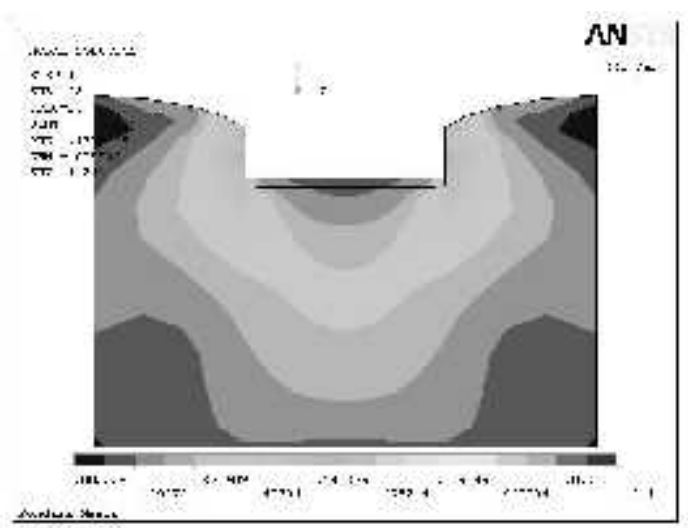

Gambar 6. Potongan Melintang Distribusi Tegangan Tanah Akibat Beban Dinamis Vetikal pada Frekuensi Kerja $25 \mathrm{~Hz}$ 


\section{Data Material}

Material struktur pondasi mesin tipe portal yang digunakan dalam analisis di sini meliputi beton bertulang dan lempung lunak, dengan data material:

- $\mathrm{f}^{\prime} \mathrm{c}=30 \mathrm{Mpa}$

- $\mathrm{Ec}=4700 \sqrt{30} \mathrm{Mpa}(\mathrm{SNI}$ 03-28472002)

$$
=25742,96 \mathrm{MPa}
$$

- $\delta \mathrm{c}=0,07$ (Earthquake Spektra and Design-Earthquake Research Institute)

Besaran modulus young dan angka poisson mengikuti Tabel 1 sesuai yang diberikan oleh Pulikanti and Ramancharla (2010).

Table 1. Nilai Modulus Young, Berat Volume, dan Angka Poisson

\begin{tabular}{cccc}
\hline Material & $\begin{array}{c}\text { Young Modulus } \\
\left(\mathbf{k N} / \mathbf{m}^{\mathbf{2}}\right)\end{array}$ & $\begin{array}{c}\text { Density } \\
\left(\mathbf{t} / \mathbf{m}^{\mathbf{3}}\right)\end{array}$ & $\begin{array}{c}\text { Poisson's } \\
\text { Ratio }\end{array}$ \\
\hline Clayey Soil & $40 \times 10^{3}$ & 1.8 & 0.4 \\
Concrete Pile & $19.36 \times 10^{6}$ & 2.4 & 0.2 \\
Concrete Frame & $25 \times 10^{6}$ & 2.4 & 0.2 \\
\hline
\end{tabular}

Sumber: Pulikanti and Ramancharla, 2010

Berdasarkan Tabel 1 di atas nampak bahwa besarnya modulus young lempung lunak, Es $=40 \times 10^{3} \mathrm{kN} / \mathrm{m}^{2}$ dan untuk beton besarnya adalah relatif sama seperti yang diberikan oleh SNI-03-2847-2002 (2002), yaitu $\mathrm{Ec}=25 \times 10^{6} \mathrm{kN} / \mathrm{m}^{2}$. Sedangkan nilai angka poisson untuk lempung lunak dan beton secara berturut-turut adalah, $v \mathrm{~s}=0,4$ dan $v \mathrm{c}=0,2$.

\section{Pembebanan}

Beban mati generator diberikan pada setiap pertemuan balok-kolom pondasi yang juga merupakan titik perletakan paket mesin (anker-bolt). Generator mempunyai berat mati sebesar 50 ton. Beban ini didistribusikan ke setiap penopang mesin secara proporsional. Penopang mesin (anker-bolt) berada tepat di pertemuan balok dan kolom pada portal pondasi. Sehingga kolom bagian dalam (2 kolom) menerima beban sebesar 12,5 ton/kolom, sedangkan kolom bagian luar (4 kolom) masing-masing menerima beban 6,25 ton. Beban-beban ini di aplikasikan ke pertemuan balok-kolom berupa beban permukaan (surface load) pada elemen yang terletak di tengah-tengahnya. Besarnya luasan elemen yang dibebani adalah:

$$
A=(0,5 \times 0,5) / 9 \quad=0,028 \mathrm{~m}^{2} \text {. }
$$

Sehingga untuk kolom bagian luar surface load yang diberikan adalah sebesar:

$$
p=\frac{P}{A}=\frac{6250}{0,028}=225000 \mathrm{~kg} / \mathrm{m}^{2}
$$

dan untuk kolom bagian dalam sebesar:

$$
p=\frac{P}{A}=\frac{12500}{0,028}=450000 \mathrm{~kg} / \mathrm{m}^{2}
$$

Beban dinamis yang bekerja adalah tipe rotating. Di mana meskipun keadaan awal mesin sebelum dipasang adalah dalam kondisi seimbang, tetapi keadaan aktual pada saat bekerja selalu terjadi beberapa ketidakseimbangan akibat sumbu putaran yang tidak segaris dengan sumbu inersia unit secara keseluruhan. Dalam kasus mesin putaran sangat tinggi, eksentrisitas yang kecil dapat mengakibatkan gaya unbalance yang besar. Gambar 7 menunjukkan suatu tipikal massa yang diputar di mana massa $\mathrm{m}_{\mathrm{e}}$ ditempatkan pada suatu as pemutar pada suatu eksentrisitas e dari pusat putaran.

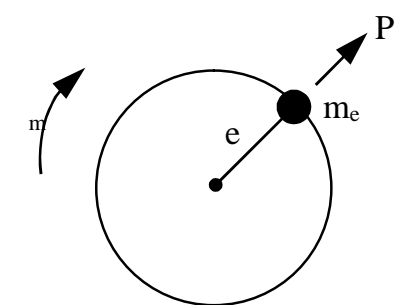

Gambar 7. Rotating Mass tipe Osilator

Kondisi yang demikian ini akan menyebabkan gaya unbalance vertikal dan horizontal dengan perbedaan fase sebesar $\pi / 2$, sehingga gaya unbalance vertikal bisa dituliskan sebagai:

$$
\mathrm{P}=\mathrm{m}_{\mathrm{e}} \mathrm{e} \omega_{\mathrm{m}}^{2} \sin \left(\omega_{\mathrm{m}} \mathrm{t}\right)
$$


Sedangkan gaya pada arah horisontal adalah sebesar:

$$
\mathrm{P}=\mathrm{m}_{\mathrm{e}} \mathrm{e} \omega_{\mathrm{m}}^{2} \sin \left(\omega_{\mathrm{m}} \mathrm{t}-\frac{\pi}{2}\right)
$$

Gambar 8 menunjukkan besarnya gaya unbalance $\mathrm{P}$ pada arah vertikal dan horisontal fungsi waktu. Besarnya beban unbalance yang bekerja pada saat mesin beroperasi dihitung seperti berikut ini:

- Kecepatan generator $=1500 \mathrm{rpm}$

$$
\begin{aligned}
& =25 \mathrm{~Hz} \\
& =157,08 \mathrm{rad} / \mathrm{s}
\end{aligned}
$$$$
\text { - Eksentrisitas } \quad=186 \mathrm{~mm}
$$$$
\text { - Massa unbalance } \quad=62,3 \mathrm{~g}
$$

Sehingga, gaya unbalance arah horizontal dan vertikal masing-masing adalah sebesar:

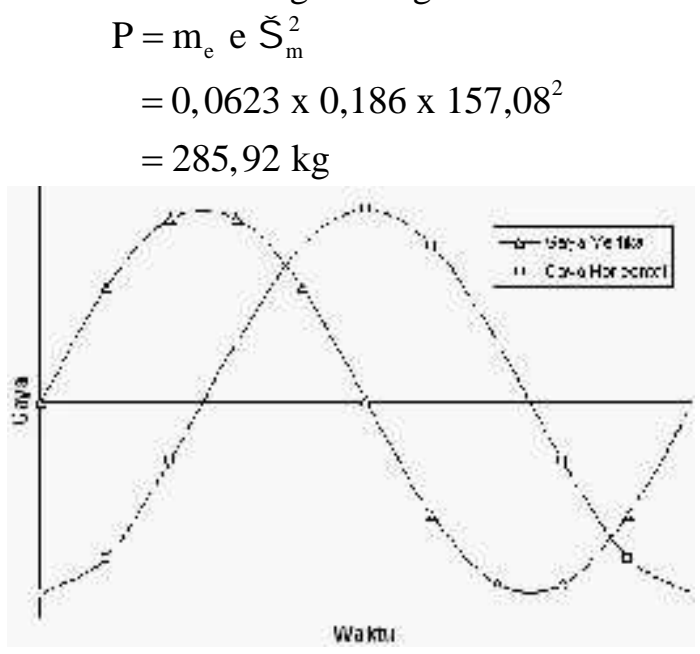

Beban tersebut adalah total beban dinamis mesin, distribusi beban yang dilakukan adalah sama seperti pada pembebanan beban mati. Di mana masingmasing titik pada kolom bagian luar menerima beban unbalance sebesar $285,93 / 8=35,74 \mathrm{~kg}$. Kolom bagian dalam menerima $285,93 / 4=71,48 \mathrm{~kg}$. Pemberian beban pada model diwakili oleh 4 titik yang membentuk sisi atas elemen yang terletak di tengah pertemuan balok-kolom, yang besarnya: $8,935 \mathrm{~kg}$ dan $17,87 \mathrm{~kg}$ untuk masing-masing kolom bagian luar dan kolom bagian dalam.

\section{HASIL DAN PEMBAHASAN}

Dari analisis harmonis pada model pondasi mesin diperoleh nilai simpangan pada frekuensi kerja $25 \mathrm{~Hz}$ yang bervariasi, nilai ini ditampilkan pada Tabel 2 dan Tabel 3. L/H adalah nilai perbandingan lebar terhadap tinggi portal pondasi, sedangkan $K_{R}$ adalah nilai perbandingan kekakuan balok terhadap kolom.

Gambar 8. Gaya Unbalance

Tabel 2. Respon Struktur pada $\mathrm{f}_{\mathrm{m}}=25 \mathrm{~Hz}$ untuk Pembebanan Dinamis Vertikal

\begin{tabular}{ccccccccc}
\hline \multirow{2}{*}{ L/H } & \multirow{2}{*}{$\mathbf{K}_{\mathbf{R}}$} & \multicolumn{2}{c}{ Jepit } & \multicolumn{2}{c}{ SSI } & \multicolumn{2}{c}{ Rasio } \\
\cline { 3 - 9 } & & $\mathbf{U x}$ & $\mathbf{U y}$ & $\mathbf{U x}$ & $\mathbf{U y}$ & $\mathbf{U v x}$ & $\mathbf{U v y}$ \\
\hline 0.55 & 2.11 & $1.50 \mathrm{E}-09$ & $5.78 \mathrm{E}-08$ & $1.16 \mathrm{E}-09$ & $8.89 \mathrm{E}-07$ & 1.29 & 0.06 \\
0.55 & 6.16 & $4.84 \mathrm{E}-10$ & $7.66 \mathrm{E}-08$ & $2 \mathrm{E}-09$ & $9.03 \mathrm{E}-07$ & 0.24 & 0.08 \\
0.55 & 49.30 & $2.74 \mathrm{E}-12$ & $2.01 \mathrm{E}-07$ & $6.37 \mathrm{E}-11$ & $8.3 \mathrm{E}-07$ & 0.04 & 0.24 \\
0.55 & 166.38 & $3.14 \mathrm{E}-10$ & $2.14 \mathrm{E}-07$ & $2.49 \mathrm{E}-10$ & $7.74 \mathrm{E}-07$ & 1.26 & 0.28 \\
0.91 & 0.46 & $4.48 \mathrm{E}-17$ & $2.33 \mathrm{E}-07$ & $8.29 \mathrm{E}-16$ & $5.5 \mathrm{E}-07$ & 0.05 & 0.42 \\
0.91 & 1.33 & $3.89 \mathrm{E}-17$ & $2.57 \mathrm{E}-07$ & $6.23 \mathrm{E}-18$ & $1.04 \mathrm{E}-06$ & 6.23 & 0.25 \\
0.91 & 10.65 & $1.07 \mathrm{E}-16$ & $2.59 \mathrm{E}-07$ & $3.63 \mathrm{E}-16$ & $5.78 \mathrm{E}-07$ & 0.29 & 0.45 \\
0.91 & 35.94 & $1.74 \mathrm{E}-17$ & $2.38 \mathrm{E}-07$ & $5.37 \mathrm{E}-17$ & $5.85 \mathrm{E}-07$ & 0.32 & 0.41 \\
1.27 & 0.17 & $6.39 \mathrm{E}-09$ & $3.59 \mathrm{E}-07$ & $5.75 \mathrm{E}-09$ & $3.5 \mathrm{E}-07$ & 1.11 & 1.02 \\
1.27 & 0.49 & $6.86 \mathrm{E}-09$ & $3.51 \mathrm{E}-07$ & $4.69 \mathrm{E}-09$ & $3.69 \mathrm{E}-07$ & 1.46 & 0.95 \\
1.27 & 3.88 & $3.75 \mathrm{E}-09$ & $2.93 \mathrm{E}-07$ & $2.6 \mathrm{E}-09$ & $4.27 \mathrm{E}-07$ & 1.44 & 0.69 \\
1.27 & 13.10 & $1.64 \mathrm{E}-09$ & $2.58 \mathrm{E}-07$ & $8.33 \mathrm{E}-10$ & $4.52 \mathrm{E}-07$ & 1.97 & 0.57 \\
2.00 & 0.04 & $3.78 \mathrm{E}-09$ & $5.70 \mathrm{E}-07$ & $1.41 \mathrm{E}-09$ & $3.18 \mathrm{E}-07$ & 2.67 & 1.79 \\
2.00 & 0.13 & $1.32 \mathrm{E}-08$ & $4.77 \mathrm{E}-07$ & $1.04 \mathrm{E}-07$ & $2.18 \mathrm{E}-07$ & 0.13 & 2.18 \\
2.00 & 1.00 & $2.14 \mathrm{E}-09$ & $3.47 \mathrm{E}-07$ & $6.98 \mathrm{E}-10$ & $2.18 \mathrm{E}-07$ & 3.06 & 1.59 \\
2.00 & 3.38 & $1.13 \mathrm{E}-09$ & $2.92 \mathrm{E}-07$ & $2.49 \mathrm{E}-10$ & $2.45 \mathrm{E}-07$ & 4.54 & 1.19 \\
\hline
\end{tabular}


Tabel 3. Respon struktur pada $\mathrm{f}_{\mathrm{m}}=25 \mathrm{~Hz}$ untuk Pembebanan Dinamis Horizontal

\begin{tabular}{cccccccc}
\hline \multirow{2}{*}{$\mathbf{L} / \mathbf{H}$} & \multirow{2}{*}{$\mathbf{K}_{\mathbf{R}}$} & \multicolumn{2}{c}{ Jepit } & \multicolumn{2}{c}{ SSI } & \multicolumn{2}{c}{ Rasio } \\
\cline { 3 - 8 } & & $\mathbf{U x}$ & $\mathbf{U y}$ & $\mathbf{U x}$ & Uy & Uhx & Uhy \\
\hline 0.55 & 2.11 & $6.45 \mathrm{E}-05$ & $7.17 \mathrm{E}-07$ & $1.95 \mathrm{E}-06$ & $3.79 \mathrm{E}-07$ & 33.06 & 1.89 \\
0.55 & 6.16 & $6.32 \mathrm{E}-05$ & $1.37 \mathrm{E}-07$ & $2.92 \mathrm{E}-06$ & $2.48 \mathrm{E}-07$ & 21.65 & 0.55 \\
0.55 & 49.30 & $1.96 \mathrm{E}-05$ & $1.11 \mathrm{E}-07$ & $3.18 \mathrm{E}-06$ & $1.17 \mathrm{E}-07$ & 6.14 & 0.95 \\
0.55 & 166.38 & $1.09 \mathrm{E}-05$ & $8.03 \mathrm{E}-08$ & $3 \mathrm{E}-06$ & $7.74 \mathrm{E}-08$ & 3.64 & 1.04 \\
0.91 & 0.46 & $5.76 \mathrm{E}-05$ & $9.15 \mathrm{E}-16$ & $1.58 \mathrm{E}-05$ & $8.23 \mathrm{E}-17$ & 3.65 & 11.12 \\
0.91 & 1.33 & $4.10 \mathrm{E}-05$ & $1.04 \mathrm{E}-16$ & $6.1 \mathrm{E}-06$ & $3.11 \mathrm{E}-16$ & 6.72 & 0.34 \\
0.91 & 10.65 & $1.36 \mathrm{E}-05$ & $4.55 \mathrm{E}-15$ & $1.14 \mathrm{E}-06$ & $4.33 \mathrm{E}-16$ & 12.02 & 10.50 \\
0.91 & 35.94 & $8.29 \mathrm{E}-06$ & $8.21 \mathrm{E}-18$ & $1.64 \mathrm{E}-06$ & $3.79 \mathrm{E}-17$ & 5.05 & 0.22 \\
1.27 & 0.17 & $2.89 \mathrm{E}-05$ & $6.05 \mathrm{E}-07$ & $4.65 \mathrm{E}-05$ & $1.76 \mathrm{E}-06$ & 0.62 & 0.34 \\
1.27 & 0.49 & $2.26 \mathrm{E}-05$ & $3.11 \mathrm{E}-07$ & $3.19 \mathrm{E}-05$ & $1.03 \mathrm{E}-06$ & 0.71 & 0.30 \\
1.27 & 3.88 & $1.02 \mathrm{E}-05$ & $2.96 \mathrm{E}-08$ & $7.23 \mathrm{E}-06$ & $2.46 \mathrm{E}-07$ & 1.41 & 0.12 \\
1.27 & 13.10 & $6.77 \mathrm{E}-06$ & $4.85 \mathrm{E}-09$ & $1.72 \mathrm{E}-06$ & $1.14 \mathrm{E}-07$ & 3.93 & 0.04 \\
2.00 & 0.04 & $1.46 \mathrm{E}-05$ & $3.30 \mathrm{E}-07$ & $1.49 \mathrm{E}-05$ & $4.19 \mathrm{E}-07$ & 0.98 & 0.79 \\
2.00 & 0.13 & $1.16 \mathrm{E}-05$ & $1.69 \mathrm{E}-07$ & $1.26 \mathrm{E}-05$ & $2.69 \mathrm{E}-07$ & 0.92 & 0.63 \\
2.00 & 1.00 & $8.90 \mathrm{E}-06$ & $3.11 \mathrm{E}-08$ & $7.96 \mathrm{E}-06$ & $9.59 \mathrm{E}-08$ & 1.12 & 0.32 \\
2.00 & 3.38 & $3.94 \mathrm{E}-06$ & $1.09 \mathrm{E}-08$ & $5.71 \mathrm{E}-06$ & $7.17 \mathrm{E}-08$ & 0.69 & 0.15 \\
\hline
\end{tabular}

Rasio simpangan merupakan perbandingan respon harmonis yang terjadi pada model jepit dibandingkan dengan model SSI. Model dikatakan bisa dianggap jepit jika mempunyai rasio simpangan lebih besar atau sama dengan 1. Gambar 9, Gambar 10, Gambar 11 dan Gambar 12 menggambarkan besarnya rasio simpangan pada $\mathrm{L} / \mathrm{H}$ antara 0,55 sampai dengan 2,00. Tampak bahwa tidak semua respon bisa

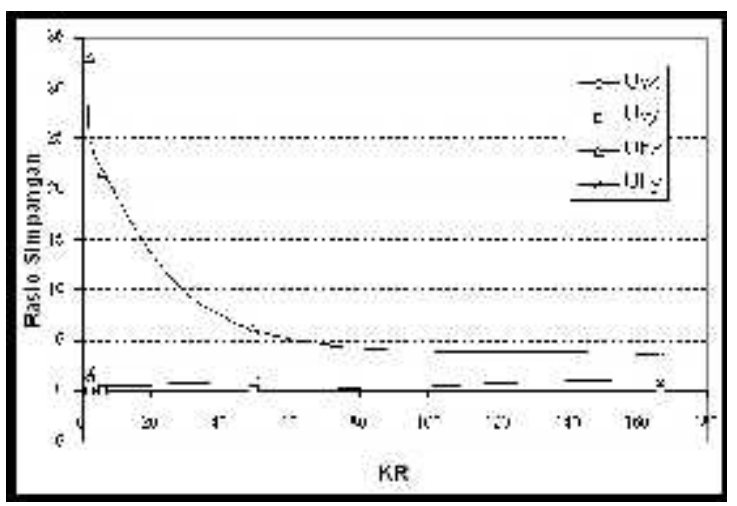

Gambar 9. Respon pada nilai $\mathrm{L} / \mathrm{H}=0,55$ mencapai rasio simpangan yang lebih besar atau sama dengan 1. Meskipun demikian, respon tersebut menunjukkan lintasan yang relatif konstan pada suatu nilai $\mathrm{K}_{\mathrm{R}}$ tertentu. Untuk keadaan ini, maka kondisi jepit untuk tiap-tiap nilai $\mathrm{L} / \mathrm{H}$ bisa ditentukan pada saat lintasan grafik yang terjadi adalah relatif mendatar, yang menggambarkan bahwa rasio simpangan yang terjadi adalah konstan.

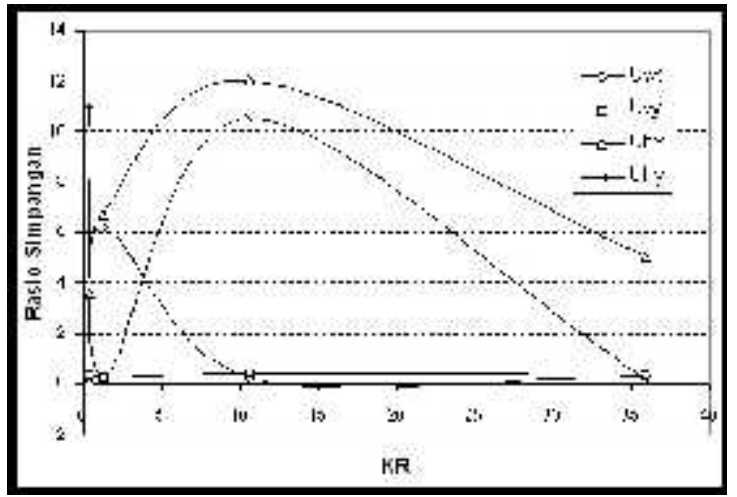

Gambar 10. Respon pada nilai $\mathrm{L} / \mathrm{H}=0,91$ 


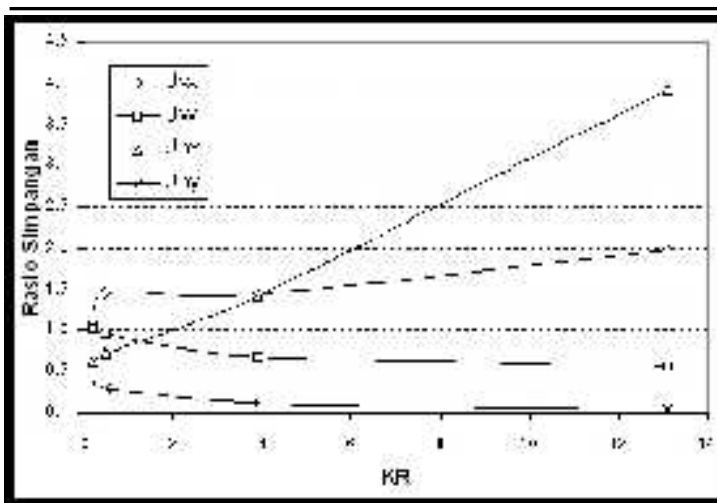

Gambar 11. Respon pada nilai $\mathrm{L} / \mathrm{H}=1,27$

Berdasarkan hal tersebut di atas, maka grafik hubungan $\mathrm{L} / \mathrm{H}$ terhadap $\mathrm{K}_{\mathrm{R}}$ bisa ditentukan. Gambar 13 menunjukkan hubungan antara $\mathrm{L} / \mathrm{H}$ dan $\mathrm{K}_{\mathrm{R}}$, di mana sumbu $\mathrm{X}$ mewakili nilai $\mathrm{L} / \mathrm{H}$ dalam skala linear dan sumbu $\mathrm{Y}$ mewakili nilai $\mathrm{K}_{\mathrm{R}}$ dalam skala logaritmis. Dengan

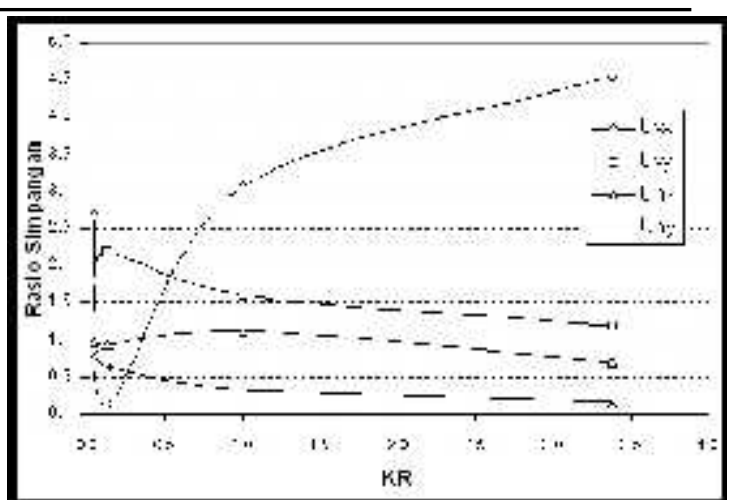

Gambar 12. Respon pada nilai $\mathrm{L} / \mathrm{H}=2,00$

menggunakan grafik ini, pondasi mesin tipe portal yang dihitung dengan anggapan perletakan jepit akan mempunyai respon struktur yang setara dengan keadaan pondasi mesin yang dalam perhitungannya mempertimbangkan terjadinya efek SSI.
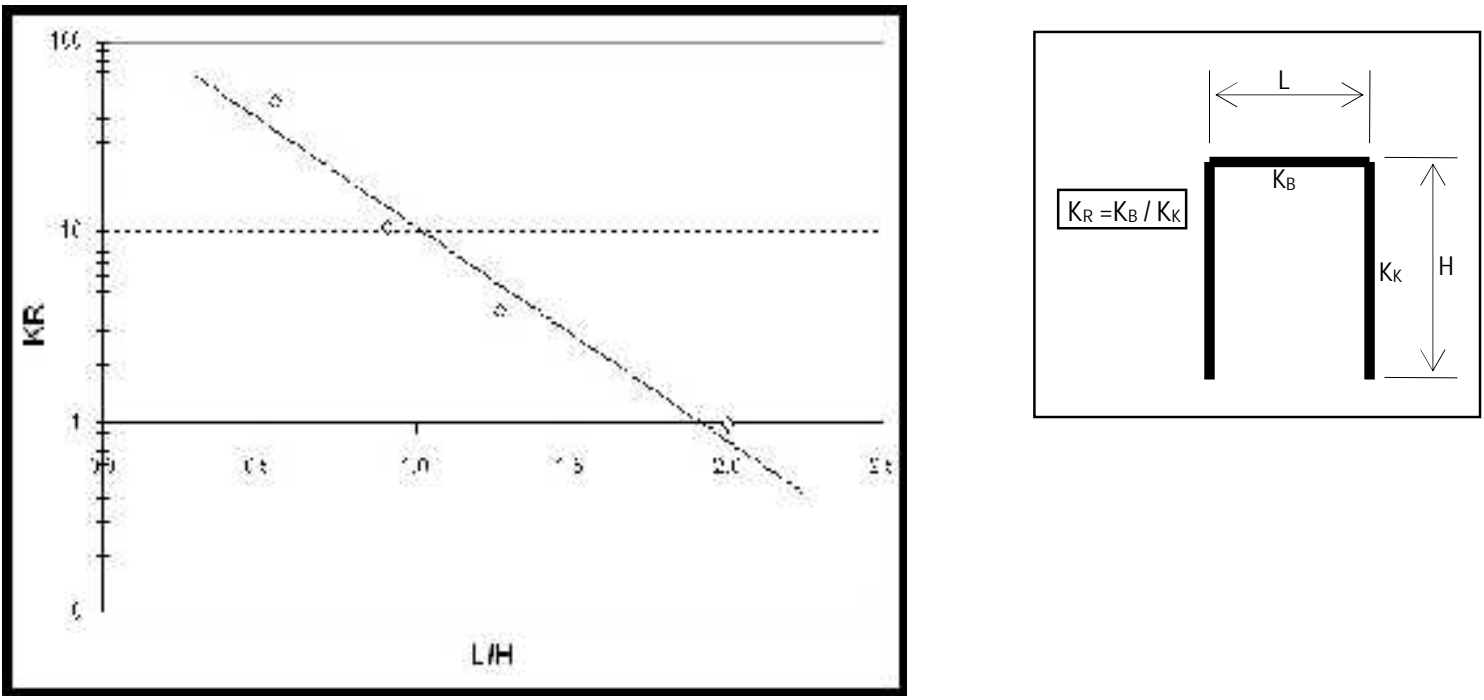

Gambar 13. Grafik L/H terhadap $K_{R}$ pada Saat Dicapai Kondisi Jepit

Grafik di atas bisa digunakan untuk menghitung pondasi mesin tipe portal dengan menggunakan perletakan jepit yang hasilnya akan setara dengan dengan perhitungan yang di dalamnya memasukkan pertimbangan terjadinya efek SSI. Dalam penelitian sebelumnya (Wahyudi, 2006) menyatakan besarnya perbedaan respon horizontal yang terjadi dengan penambahan variasi kekakuan pada kolom berupa taper yang diterapkan pada system perletakan jepit dan SSI. Tanah yang ditinjau meliputi lempung, lempung keras, dan tanah pasir. Sedangkan dalam penelitian ini secara garis besar adalah memberikan kondisi tentang terjadinya kondisi jepit pada struktur pondasi mesin tipe portal dengan mempertimbangakan terjadinya efek SSI.

\section{KESIMPULAN}

Kondisi jepit pada struktur pondasi mesin tipe portal dicapai dengan kondisi nilai perbandingan lebar terhadap tinggi portal yang berbanding lurus dengan logaritma nilai perbandingan kekakuan balok dan kolom portal dengan kemiringan garis -1,13. Dalam keadaan ini, struktur pondasi bisa dianggap sebagai terjepit.

Untuk keperluan perhitungan pondasi mesin tipe portal yang berada di atas 
lempung lunak dengan anggapan perletakan jepit, disarankan untuk mengikuti garis pada grafik hubungan $\mathrm{L} / \mathrm{H}$ terhadap $\mathrm{K}_{\mathrm{R}}$ yang sudah didapatkan. Perhitungan yang mengambil titik di daerah di bawah garis akan memberikan respon struktur yang lebih besar, karena kondisi pondasi yang lebih lentur. Sedangkan pengambilan titik yang berada di daerah di atas garis akan memberikan respon struktur yang lebih aman, tetapi struktur menjadi terlalu kaku dan boros.

\section{Ucapan Terima Kasih}

Seiring puji sukur kepada Tuhan Yang Maha Esa kami sampaikan ucapan terima kasih yang sedalam-dalamnya kepada Ndaru Supraba, dan Yogie Risdianto yang sudah memberikan waktunya untuk diskusi dan masukan untuk artikel ini dan juga kepada pihak Jurusan Teknik Sipil Unesa dan Jurusan Teknik Sipil ITS yang telah memberikan kesempatan untuk melakukan penyusunan tulisan ini.

\section{DAFTAR PUSTAKA}

ANSYS, Inc (2005): ANSYS Theory Reference, SAS IP, Inc., U.S.

Aron, C. and Jonas, E. (2012): Structural Element Approaches for Soil-Structure Interaction, Chalmers University of Technology, Goteborg.

Grange, S. (2013): Simplied Modeling Strategies for Soil-Structure Interaction Problems: The Macro-Element Concept, Universite Joseph Fourier/Laboratoire 3SR - Grenoble, Aussois.

Japan Society of Civil Engineers. Standard Specifications for Concrete Structures (2002): Seismic Performance Verification, JSCE Guidelines for Concrete No. 5, 2005.

Kolekova, Y., Petronijevic, M., Schmid, G. (2010): Special Dynamic Soil-Structure Analysis Procedures Demonstrated for Two Tower-Like Structures, Slovak Journal of Civil Engineering, Slovakia.

Mylonakis, G. and Gazetas, G. (2000): Seismic soil structure interaction: Beneficial or Detrimental?, Journal of Earthquake Engineering, Vol. 4(3), pp. 277-301.

Mylonakis, G., Gazetas, G., Nikolaou, S., and Michaelides, O. (2000): The Role of Soil on the Collapse of 18 Piers of the Hanshin Expressway in the Kobe Earthquake, Proceedings of $12^{\text {th }}$ World Conference on Earthquake Engineering, New Zealand, Paper No. 1074.

Padron, L. A., Aznarez, J. J., Maeso, O. (2009): Dynamic structure-soil-structure interaction of near by piled buildings under seismic excitation by using BEM-FEM model, Soil Dynamics and Earthquake Engineering, 29:1084-1096.

Pulikanti, S. and Ramancharla, P. K. (2010): Dymanic Soil Structure Interaction Analysis of Pile Supported High Rise Structures, Fifth International Conferences on Recent Advances in Geotechnical Earthquake Engineering and Soil Dynamics, San Diego.

SNI 03-2847-2002 (2002): Tata Cara Perhitungan Struktur Beton untuk Bangunan Gedung, BSN, Bandung.

Stewart, J. P., Cormatin, C., Moehle, J. P. (2004): Implementation of Soil-Structure Interaction Models in Performance Based Design Procedures, 13 ${ }^{\text {th }}$ World Conference on Earthquake Engineering, Vancouver.

Suleyman, K., Yalcin, M. (2000): A Simple Soil-Structure Interaction Model, Applied Mathematical Modelling 24 (2000) 607-635, Elsevier Science Inc.

Tsogka, C. and Wirgin, A. (2003): Simulation of seismic response in an idealized city, Soil Dynamics and Earthquake Engineeirng, 23; 391-402.

Tuladhar, R., Maki, T., Mutsuyoshi, H. (2008): Cyclic behavior of laterally loaded concrete piles embedded into cohesive soil, Earthquake Engineering \& Structural Dynamics, Vol. 37 (1), pp. 43-59.

Wahyudi, L. (2006): Analisis Pengaruh Kolom Nonprismatik pada Struktur Frame Penopang Mesin terhadap Daya Dukung Struktur, Tesis Pascasarjana Program Magister Jurusan Teknik Sipil Institut Teknologi Sepuluh Nopember, Surabaya. 